\title{
Conclusion
}

\section{Schoolteachers and the Nordic model}

\author{
Jesper Eckhardt Larsen, Barbara Schulte and Fredrik W.Thue
}

To what extent can we talk about a Nordic model, and how have schoolteachers interacted with and contributed to such a model? As argued in the Introduction, the notion of a 'Nordic model' has served as an instrument of internal regional identity-building as well as of external cultural and political diplomacy. Nordic references were mobilised in Denmark against the threat from Germany since the second half of the nineteenth century, in Finland after the civil war, and in most of the Nordic countries during and after the Second World War, not least during the ideologically polarised Cold War. Particularly during the twentieth century, the Nordic societal model functioned largely as a canvas on which the outside world projected its utopian - and sometimes dystopian - ideological dreams.

The contributions to this volume have studied Nordic schoolteachers comparatively and historically as a patchwork of national historical trajectories, which, while converging and interacting at certain points, have also been distinct and, in some respects, contrasting. Can we nonetheless identify some crucial commonalities or family resemblances between the five countries' educational traditions and teachers' roles and cultures in support of the hypothesis of a common Nordic path? If so, what is the proper historical outlook for identifying such a Nordic distinctiveness - how deeply into the past should its origins be traced? Finally, how have the Nordic countries responded to a new era of globalisation, neoliberalism, international student assessments, and increasing output control of teacher performance? Has (any) distinct Nordicness in education declined or evaporated through immersion into global trends?

The questions raised in this conclusion are thus directed towards a historical assessment of whether, or to what extent, a distinct Nordicness can be found within the field of education and teacher cultures, as well as towards the similarities and differences between the Nordic countries in each of the three areas covered by this volume: schoolteachers in the context of a Nordic model; Nordic teacher education; and Nordic teachers, their professional identities and practices, and their governance.

\section{Schoolteachers in the context of a Nordic model}

The 'Nordic model' can be approached either with a view from the outside, or from within. As a widely circulating stereotype during the period since the Second World War, the 'Nordic model' has tended to privilege the case of Sweden, as if this 
country incarnated more general qualities of the Nordic region or found itself at the vanguard of a distinctively Nordic trajectory of democratisation and modernisation. This view from the outside has also typically concentrated on the heyday of social democracy and of the welfare state as the high point and telos of Nordic modernity.

Viewed from the inside, a distinct, shared Nordic perspective on education was, arguably, the earliest and maybe even the sole successful outcome of the political movement to create some kind of 'real' Scandinavian unity in the second half of the nineteenth century. There are diverse interpretations of the discontinuities between the earlier Scandinavianism and later Nordic cooperation (Hemstad, 2010). However, for the educationalists involved, this discontinuity was perhaps less overt. As mentioned in the Introduction, the first 'Nordic school meeting' for regional networking was to take place in Denmark but was prevented from occurring by the war with Prussia and Austria in 1864 (De nordiska skolmötenas silfverbröllop, 1895). Scandinavianism as a political movement proved unable to mobilise military forces in defence of Denmark but, during and after the war, the idea of an educational-cum-cultural counterreaction to the defeat and loss of Danish territory became very prominent in the minds and hearts of many Danish and Nordic actors within the field of education (Skovmand, 1983; Nielsen, 1995). Nordicness in education, as epitomised by the folk high-school movement, crystallised in the form of recurrent school meetings over the following century. This established an arena of interchange and communication of educational ideas. The share of active schoolteachers as participants in these meetings was substantial (Landahl, 2015).

The contributions to this volume have identified several important similarities and differences between education in the Nordic countries even before the first manifestation of a common Nordic educational arena. While Denmark-Norway made the first attempt to implement mandatory elementary schooling as early as 1739, Sweden only followed suit a century later, and Iceland and Finland did not introduce compulsory school attendance until 1907 and 1921, respectively. The balance between top-down and bottom-up forces in the formation and reformation of national school systems and teacher education has also varied between the Nordic countries as well as over time in each country.

The volume shows a diverse and multifaceted picture of how teachers across the region were emissaries of the state and how some formed groups with their own distinct agendas. The late eighteenth and early nineteenth-century schoolteachers were, for political as well as social reasons, humble servants of the absolutist state and the church, and had to align with their top-down initiatives. This can be seen very clearly in the Danish implementation of the monitorial system of instruction in the beginning of the nineteenth century, where the king simply overruled all opposition among schoolteachers and the clergy in an absolutist move (Reeh and Larsen, 2014). In the second half of the nineteenth century, however, teachers generally assumed a more assertive role, with emerging teacher unions and individual teachers becoming politically active in early processes of democratisation. Not least in countries that developed strong rural countercultural movements, such as Norway and Denmark, the politicisation of teachers had farreaching consequences. 
The dual character of these late-nineteenth-century teachers as organic intellectuals of the people, and at the same time, as servants of a nation-building state, was, to some extent, in continuity with the past. The history of the 'teacher as peasant', which Christian Larsen presents in Chapter 3, neatly epitomises the ambivalent position of teachers as role models of and for the people. By cultivating their own piece of land, teachers became part of the local community and public emissaries of innovation and industriousness on behalf of a modernising state. Thue, in Chapter 2, argues that the amphibiousness of the teacher's role echoed that of the pastor in earlier times, who in the late eighteenth century, was often labelled 'folk teacher'. Thinly dispersed throughout the country, both pastors and teachers were 'frontline public servants' in close contact with local communities and the life world of their 'subjects'. Thue thus emphasises continuity, arguing that Nordic teachers' double role as disseminators of officially esteemed values, and caretakers of children's subjectivity, reflects a complex religious heritage: Lutheranism's seemingly paradoxical combination of rigid religious confessionalisation driven by the state and a radical religious subjectivity and individualism leading to lay revivalism.

The idea of a folk teacher, however, assumed a new and potentially revolutionary meaning when the concept of 'folk' changed from signifying a subservient role under a guardian state into a category of sovereignty in the democratised nationstate (Korsgaard, 2012). The Nordic countries have been described as being discursively dominated by a continuity of positive political connotations of the 'folk' concept since the late nineteenth century (Trägårdh, 1990). Briefly summarised, an alliance emerged between liberal farmers and reformist social-democratic workers in the early twentieth century. The Nordic conception of 'folk' was thus coloured by liberalism in combination with reformist, democratic socialism and was distinguished by class compromise. It thereby departed from the völkisch ideologies instrumentalised from the 1920s onwards in Germany (ibid.).

The Scandinavian comprehensive school systems of the period following the Second World War have, arguably, been shaped by this collaboration and compromise between liberal and social-democratic parties and movements (Wiborg, 2009). The exact way these political forces interacted in the formation of comprehensive school systems varied from country to country. In late-nineteenth-century Sweden, liberal and labour political mobilisation largely concurred and elementary schoolteachers were roughly equally divided in their support for the two parties. In Denmark and Norway, a broad liberal-democratic movement arose several decades before the labour movement came of age, and liberals took the first decisive steps towards a comprehensive national school system. In Norway after 1945, the governing Labour Party implemented a comprehensive lower-secondary school which, while strongly inspired by the Swedish example, could also be seen as a continuation of previous liberal-progressive educational policies. In Denmark, social democrats were less hegemonic and partly governed in coalition with the liberal-progressive party Radikale Venstre. Educational reforms were less pervasive; the Danish folk school remained deeply influenced by the Grundtvigian heritage of the late nineteenth century, and the traditional cultural schism between primary and secondary schoolteachers endured. 
The distinctive Nordic teacher cultures that prepared the soil for the partnership between Labour-dominated governments and folk schoolteachers had been born of the rise of civil society in the nineteenth century, with a dense network of local organisations, popular movements, as well as religious and national revivalism. The folk high-school movement represented a crucial link between these currents and primary teachers' coming-of-age as a self-conscious vocational group. While uniquely strong in Denmark, the movement was also vital in Norway and Sweden. In all three countries it influenced teacher cultures and bolstered an educational ideology that stressed the intrinsic value of the folk school as a 'school for life', to use Grundtvig's term. These ideas may have enhanced the receptivity towards child-centred pedagogical methods in the early twentieth century and later contributed to deprioritising the propaedeutic and selective functions of primary schooling after the Second World War. However, there was a symptomatic difference between the national populist folk high schools of Denmark and Norway, and the more rationalist profile of their Swedish counterparts, many of which were part of the Swedish labour movement's uniquely powerful institutional network for popular education. This relates to the Nordic differences analysed in Jesper Eckhardt Larsen's chapter (Chapter 1) between the more 'organic' Danish and Norwegian teachers and their more 'colonising' Swedish, Finnish, and Icelandic colleagues, which reverberated in twentieth-century school development and teacher cultures. Larsen bases this characterisation on observations of more centralised and statist forms of control, as distinct from civil society control of teacher education institutions from around 1880 to 1920 , as well as on data on recruitment patterns and the location of preservice teacher education institutions.

As community leaders and politically active agents, teachers in Sweden on the one hand, and Denmark and Norway on the other, were less contrasting. Like their Danish and Norwegian colleagues, Swedish teachers were often leaders in organisations and movements in their local communities and shared some characteristics of organic intellectuals. However, the general Swedish teacher culture was, arguably, of a more top-down, rationalist, and statist kind. The harsh opposition between the urban elites and rural countercultural Norwegian and Danish groups of teachers was not to be found in the Swedish case, where relations between academic life and the 'folk' were more harmonious, or, if expressed in a more critical way, of a more hierarchical nature. The Finnish case, on the other hand, shows a full victory of the urban elites within the field of education. In Iceland, the picture is that of strong integration between folk and state, without the existence of strongly countercultural institutions within the field of teacher education.

As also argued in the chapter by Jesper Eckhardt Larsen (Chapter 1), the organic teacher type was not without a colonising and statist function. Thus, Norwegian and Danish teachers were not free of 'colonising' traits as they operated as emissaries of Christianity and nationalism among the Sami population of North Norway, the Inuit in Danish Greenland, and in the disputed border area of Schleswig/South Jutland. Within national borders, the strategy towards minorities could be quite assimilative in these two otherwise culturally defensive countries. Teachers of the organic type may even have helped reproduce subtle inequalities: as not only 
emissaries of the state but also cultural mediators between state and civil society, who met the people on an equal standing as 'folk teachers', they may indeed have been more efficient disseminators of cultural nationalism and state loyalty than the more unambiguously colonising teacher type. The more colonising teacher type found in Sweden, Finland and, to some extent, also in Iceland can thus, by contrast, be seen as characterised by a more urban and perhaps cosmopolitan outlook.

One of the most crucial points of convergence between the different Nordic trajectories was the common propensity of elementary schoolteachers to align with 'progressive' parties and movements to introduce and expand comprehensive school systems dominated by their own cultural and vocational values. From the late nineteenth century to the interwar period, Nordic elementary schoolteachers strongly endorsed liberal and/or social-democratic initiatives to build a common folk school as a crucial instrument of nation-building, democracy, and egalitarianism. After the Second World War, folk schoolteachers enthusiastically supported the integration of the lower-secondary school into an expanded scheme of compulsory comprehensive schooling. They saw their jurisdiction and career opportunities boosted by Labour-dominated governments which argued that a unified compulsory school required a unified teaching profession. A core defining feature of the 'Nordic model' of education was the close cooperation between progressive political forces and elementary schoolteachers in the pursuit of a comprehensive national school system. In the post-war welfare states, this cooperation was institutionalised in a corporatist form; teacher unions and expert councils took an active part in educational policymaking and the day-to-day administration of the educational system (Wiborg, 2009, 2017; Helsvig, 2017).

While a long historical continuity in Nordic education and teacher cultures can arguably be traced backwards from the post-war welfare states to the nineteenth century and even further back, from the era of absolutism and Lutheran orthodoxy, a complex and controversial question is whether, or to what extent, this continuity has been broken by new policy trends since the 1980s. These trends have included the dismantling of corporatist educational governance and the reduction of teachers' codetermination in local and central school management, increasing focus on students' measurable learning outcomes and output control of educational quality, as well as a range of measures to 'professionalise' teachers from above and hold them accountable for their performance.

\section{Nordic teacher education}

In recent decades, Finland has stood out among Nordic countries with its internationally admired system of academic teacher education, a carefully selected and uniquely autonomous teaching profession, and a school system largely steered by professionals at arm's length from the government (see Chapter 4). By contrast, the Swedish educational system has been subject to 'rolling reforms', politicisation, and marketisation, as pointed out in Chapter 13, and teachers' social status has been in marked decline. Norway seems to have found a wavering compromise between its democratic-egalitarian school tradition and new, more performance-oriented aspirations, though challenged by an ongoing though unspoken tug-of-war between 


\section{Jesper Eckhardt Larsen et al.}

the government's thrust to professionalise teachers and the teachers' pre-emptive attempts to professionalise themselves, as Mausethagen shows in Chapter 11.

In Sweden and Norway, folk schoolteacher training was upgraded and integrated into the general higher education sector in the 1970s, and new opportunities opened for continuing education with flexible combinations of teacher colleges and university credentials. While the old dualism between academically oriented upper-secondary teachers and more pedagogy- and nurture-oriented folk schoolteachers was hardly fully transcended, the entire education systems of both countries were successively reformed, from the primary and lower-secondary to the upper-secondary and tertiary school levels (see Chapter 10). The comprehensive school project thus laid the foundation for reform at a higher level, leading to a pervasive democratisation and equalisation of the entire educational system. This was particularly evident in Sweden, where even university studies became thoroughly transformed.

In Denmark, the strongly consolidated culture of the folk schoolteachers was less able to penetrate the higher levels of the school system and vice versa, and the dualism between the two teacher cultures and their respective schools largely continued. Danish social democrats, less hegemonic in national politics, and more influenced than their Swedish and Norwegian fellows by a liberal educational tradition rooted in the nineteenth century, generally showed more restraint around reforming teacher training institutions, and educational policies were shaped by coalition and compromise with the liberal and conservative opposition. In the crucial years of the common Nordic reform wave in the 1970s, the differences were consolidated between, on the one side, a more continental upper-secondary school tradition in Denmark with a continuing focus on Bildung (Danish almendannelse) and, on the other, a more Anglo-Saxon high-school inspiration in Sweden and Norway (see Chapter 10 in this volume; Haue, 2003).

Finland's trajectory is exceptional in the Nordic context (see Chapters 5, 6, 7, and 9). From around 1970, a comprehensive teacher culture was effectively created by transforming all teacher training into academic programmes organised by the universities. Preliminary initiatives to academise primary schoolteacher education were taken much earlier, as shown in Chapters 5 and 7. Still, full academisation was not realised without cultural struggles to preserve a more folk-adjacent teacher culture (Nieminen, 2018).

In Iceland, granting teacher training institutions university status in 1971 seemed a less dramatic step due to the smaller scale of the teacher training sector. This process resembled the slow integration between primary teacher training and the universities that took place in Sweden and Norway, where the education of comprehensive primary and lower-secondary teachers was integrated into higher education systems from the 1970 s onwards. Denmark is, in this respect, an outlier, not only in the Nordic area, but also compared with most other Western countries. In Denmark, primary schoolteachers are still educated in non-academic, professional, so-called 'development-based' institutions, in contrast to the 'research-based' ones now found in all the other Nordic and in most continental European countries (see Chapter 7). 


\section{Nordic teachers, their professional identities and practices, and governance}

The construction of a past with regard to education and teachers' vocational identity is intimately connected to negotiations of the present. By using the concept of professionalism and viewing schoolteachers' occupation as a profession, actors in the field seem actively to promote a notion of fundamental historical discontinuity. In a Nordic context, the 'professional teacher' represents a rather new teacher type. As shown by Mausethagen in Chapter 11, the discourse of teacher professionalism did not take off in the Nordic context before the turn of the millennium. And, clearly, it was a departure from the previous comprehensive teachers, closely connected to the educational discourse and institutions of Nordic welfare states. Now, with a new focus on performance, professionalised teachers are intended to become learning optimisers, more specialised in dealing with different age groups, and legitimising their knowledge of teaching through universal evidence-based methods.

Nordic teachers have long been characterised by close relationships with the state and have, in most instances, trustingly adopted policymakers' strategies. Even after what some have regarded as the end of corporatism, as Mausethagen's study shows, there is an enduring willingness among teachers to be bureaucratically governed. The current Nordic teaching profession is socialised into - and, in fact, often asks for - bureaucratic support in its work.

However, this common 'statism' of Nordic teachers is not mirrored in a shared Nordic model of governance. On the contrary, the Nordic countries have quite differing approaches to the governance of teachers. As several contributions to this volume show, this field is constituted differently in each country, even though an initial observation suggests that all have moved somewhat from input towards output governance, following global education trends.

The Finnish case shows most clearly a centralised and state-driven allocation of resources in advance (ex ante), financed as a public good, certified and high-level academic pre-service education of teachers, general curriculum guidelines, freedom of methods, and a low stakes educational context, with a strong continuity from the 1970s onwards, albeit challenged by recent reforms in upper-secondary vocational schools in the direction of OECD-inspired output governance.

At the other end of the spectrum is Sweden, in this respect, almost a land of extremes. Sweden turned from a highly state-driven system into an outputoriented regime in the 1980s and 1990s. This includes decentralised allocation of resources after evaluation of performance (ex post), combined with semi-market 'choice' financing (state vouchers) and high-stakes follow-up mechanisms for individual institutions. It also included a wave of privatisation, generating a whole range of so-called 'free schools' that are still completely financed by the state, but whose profits go to private companies. However, the chequered results led these moves to be partly reversed in 2008 with the introduction of central state inspectorates and national testing. The impression of the Swedish case is thus one of 'rolling reform' and 'innovation fetishism' (see Chapter 13). 
In most cases, however, Wermke and Prøitz argue for multiple and conglomerate combinations of input and output types of governance. Norwegian governance is traditionally state-centred, but with increasing municipal and output control since the turn of the millennium. Being almost exclusively public (97\% of all pupils) it thus resembles Iceland which also has an almost total state monopoly on schooling (private schooling has recently grown to 3\%). In governance, Iceland has, however, emulated a more Danish model with strong school boards with parents as members. The Danish case exhibits more traditional private characteristics - since the free school law of 1855 , it has been possible to open civil-society schooling based on distinct pedagogical ideals, and which are not-for-profit - albeit with the special twist that 'private' here means that the state pays anyway (with $80 \%$ public financing). Around $18 \%$ of all children attend private schools in Denmark. As mentioned, parents have a large say in the Danish municipal school boards of publicly financed and driven schools.

Turning to the classroom roles of teachers and their use of pedagogical approaches, several chapters in this volume (Chapters 7 and 13) describe the Nordic countries as influenced by the German Didaktik tradition. This approach has been contrasted with the Anglo-American curriculum approach as two distinct 'constitutional mindsets' (Hopmann, 2008). The question is how and to what extent each of the five countries has received, interpreted, and integrated the Didaktik approach into schooling practice. This approach is connected quite intimately with an input governance regime.

The Didaktik approach is heavily influenced by the work of Johann Friedrich Herbart and his students, and was unevenly imported into the different Nordic countries, having the greatest influence in Finland. However, since the arrival of the German idea of Bildung from the early nineteenth century onwards, each of the Nordic countries has developed both similar and differing interpretations of this shared idea. After its import from the late-eighteenth-century German use of the concept, Bildung evolved into its constituent notions of institutionalised learning and general philosophical patterns of interpretation. Thus, dannelse in Danish and Norwegian, bildning in Swedish, mentunn in Icelandic, and sivistus in Finnish have had their own trajectories in each national context.

The shared aspects of these concepts in the Nordic cases include the critical importance of the teacher's reflective interpretation of subject content in instruction. In this tradition, the teacher is responsible for elaborating the intrinsic value of a subject for the education of pupils. The Nordic tradition thus stresses that the reflective practice of teaching and pedagogy is, so to speak, the 'theology' of the teaching profession in this tradition (Chapter 7).

This approach is contrasted to the so-called curriculum approach with its roots in Anglo-American education systems. This approach is associated with the idea of building systems of public schools in which the work of teachers is explicitly directed by an authoritative agency as part of a larger curricular programme containing a statement of aims, prescribed content, textbooks (in the American case), and methods of teaching which teachers are expected to implement (Wermke and Prøitz, 2019). The curriculum approach leaves more of the normative judgements to the administrative and political levels, whereas the Didaktik approach actively 
involves teachers in the interpretative and normatively guided implementation of the intended aims and content of education.

In line with the curriculum tradition, Sweden incorporated an American testbased assessment approach soon after the Second World War, while Norway and Denmark, for example, maintained a more continental tradition until the so-called PISA shock in the early 2000s (Lundahl and Tveit, 2014; Tveit, 2014). Sweden has therefore been described as an outlier in the Nordic context. Falkenberg and Ringarp, in this volume, argue that Swedish teachers are far more limited in their professional autonomy regarding assessment than their German colleagues. The turn from input towards output governance can, partly, be interpreted as a shift in the Nordic context from a more German orientation to an increasing influence from English-speaking countries - methodologically, content-wise, and normatively.

\section{New agendas, new Nordic reactions}

Many observers and historians of education have interpreted the new policies in the Nordic region as a neoliberal turn driven by an emulation of international policy trends and incited by such transnational drivers as OECD policy recommendations and international student assessments (e.g., PISA). We choose, tentatively, to distinguish between three possible readings of these new developments: (1) an idea of necessary reforms on the basis of pressures from globalisation, (2) an evolving complex conglomerate of tradition and renewal, and (3) a specific Nordic path into the era of globalised education.

An influential contribution to the first reading in the case of Denmark was the almost officially endorsed shift from a 'welfare state' to a 'competition state'. According to the political scientist Ove Kaj Pedersen, Nordic welfare states transformed themselves into competition states as a necessary innovation due to the pressures of a globalised knowledge economy (Pedersen, 2011). A competition state aims at maximising innovation and competitiveness through a combination of high-quality mass education, scientific excellence, and networks of institutionalised cooperation between science, technology, and industry. This new interpretation, or model, of a state presented by Pedersen, was welcomed in 2013 by the Danish minister of finance, Bjarne Corydon, a member of the Social Democratic government.

In line with this reading, Waine and Wiborg argue in their chapter (Chapter 8) that we are now witnessing the dawn of a new era for education and teacher training, as countries are plunged into a changed international environment of globalisation, technological innovation, and intense economic competition. Countries are faced with the so-called 'crisis of the welfare state', the onset of fiscal austerity, demands for government efficiency, and rising disaffection with centralised, bureaucratic modes of governance. In this reading of the new era, the creation of egalitarian education structures is no longer enough, and the emphasis is now on academic excellence, which the existing institutions were not specifically designed to provide.

In line with the second reading, Wermke and Prøitz caution against too-strong dichotomies in the interpretation of recent developments. They argue that today 
there is considerable room for multiple and hybrid versions of school governance in which individual teachers, principals, students, or parents influence the direction of development. The emergence of hybrid forms of governance lays the ground for recognising the formation of a conglomeration of influences rather than a singular, state-based form of governance. From a sociohistorical point of view, they suggest an approach to understanding national teaching professions that emphasises the varying degrees of complexity of these governance regimes. Complexity is understood in terms of how the components of particular systems interact in contingent and multiple ways. In certain aspects, this second reading resembles the one taken by a recent national Norwegian report on teachers, which identifies layers upon layers of teacher roles that add up to a conglomerate, or archaeological, interpretation of the present situation (Dahl et al., 2016).

Finally, both politicians and scholars have tended towards the idea of multiple paths into a new global era. In what could be referred to as a 'sushiology' of global trends, highlighting the comparative benefits of cultural interchange, the culinary parallel was easily identified in the initiative towards a 'New Nordic School' introduced by the Danish minister of education, Christine Antorini (Ministeriet for Børn og Undervisning, 2012). Like the Copenhagen restaurant Noma, which epitomises New Nordic cuisine with clear Asian inspirations, Nordic education policymakers and practitioners should consciously play to the existing strengths of the Nordic model in a proactive and responsive reaction to competitive global agendas (Skerry, 2002; Christensen and Kristensen, 2012).

The introduction to this volume pointed to the drastic increase in both political and scholarly references to a Nordic model; a specific path into a new global environment is now quite actively being constructed, nominated, and also branded as 'Nordic'. But are these just rhetorical exercises in view of a general decline of the Nordic model? The contributions to this volume point in multiple directions and thus we cannot aim for an ultimate synthesis in this conclusion. Instead of adhering to a uniform reading of globalisation, and the 'abstract universalism of transnationally disseminated models' as well as the 'global spread of a world-level developmental and educational ideology', we have given attention to both 'deviation-generating structural elaboration' and 'the persistent diversity of socio-cultural inter-relationship networks' (Schriewer, 2003, p. 31) in the pursuit of comparing and historically interpreting schoolteachers' changing roles and cultures in the Nordic region.

\section{References}

Christensen, S. and Kristensen, J.E. (2012) 'Ny Nordisk Skole', Tubulens.net: Forum for samtidsrefleksion, 17 October 2012. Available at: https://turbulens.net/ny-nordisk-skole/ (Accessed 12 May 2021).

Dahl,T., Askling, B., Heggen, K., Iversen Kulbrandstad, L., Lauvdal,T., Qvortrup, L., Salvanes, K.G., Skagen, K., Skrøvset, S. and Thue, F.W. (2016) Om larerrollen. Et kunnskapsgrunnlag. Bergen: Fagbokforlaget.

'De nordiska skolmötenas silferbröllop' (1895) Svensk Läraretidning, 27, p. 334.

Haue, H. (2003) 'Parløb og stafet i dansk-norsk gymnasiekultur', in Slagstad, R., Korsgaard, O. and Løvlie, L. (eds.) Dannelsens forvandlinger. Oslo: Pax Forlag, pp. 210-231. 
Helsvig, K.G. (2017) Reform og rutine: Kunnskapsdepartementets historie 1945-2017. Oslo: Pax. Hemstad, R. (2010) 'Scandinavianism, Nordic co-operation and "Nordic democracy", in Kurunmäki, J. and Strang, J. (eds.) Rhetorics of Nordic democracy. Studia Fennica Historica, vol. 17. Helsinki: Finnish Literature Society, pp. 179-193.

Hopmann, S.T. (2008) 'No child, no school, no state left behind: schooling in the age of accountability', Journal of Curriculum Studies 40(4), 417-456.

Korsgaard, O. (2012) Kampen om folket: Et dannelsesperspektiv på dansk historie gennem 500 år. Copenhagen: Gyldendal.

Landahl, J. (2015) 'Det nordiska skolmötet som utbildningspolitisk arena (1870-1970): ett rumsligt perspektiv på den moderna pedagogikens historia', Utbildning $\mathcal{E}$ Demokrati 24(3), pp. 7-23. doi: 10.48059/uod.v24i3.1040.

Lundahl, C. and Tveit, S. (2014) 'Att legitimera nationella prov i Sverige och i Norge - en fråga om profession och tradition', Pedagogisk forskning $i$ Sverige (4-5), pp. 297-323.

Ministeriet for Børn og Undervisning (2012) Velkommen til Ny Nordisk Skole. Copenhagen: Ministeriet for Børn og Undervisning.

Nielsen, V. (1995) 'En dansk og nordisk kampskole', in Norlan, F. and Christiansen, E. (eds.) Harpens Kraft - Frederiksborg Højskole i 100 år. Aarhus: Systime.

Nieminen, M. (2018) 'Teachers' written school memories and the change to the comprehensive school system in Finland in the 1970s', Paedagogica Historica 55(2), pp. 253-276. doi: 10.1080/00309230.2018.1499785.

Pedersen, O.K. (2011) Konkurrencestaten. ISSN 2245-5116. København: Hans Reitzels Forlag.

Reeh, N. and Larsen, J.E. (2014) 'From competing technologies of mass schooling to the spiritual enlightenment of the nation: the reception of the monitorial system of education in Denmark 1814-1849', in Caruso, M. (ed.) Classroom struggle: organizing elementary school teaching in the 19th century. Studia Educationis Historica, vol. 2. Frankfurt: Peter Lang.

Schriewer, J. (2003) 'Comparative education methodology in transition', in Schriewer, J. (ed.) Discourse formation in comparative education, vol. 10. Frankfurt: Peter Lang, pp. 3-52.

Skerry, P. (2002) 'Beyond sushiology: does diversity work?', Brookings Review 20(1), pp. 20-23. doi: 10.2307/20081016.

Skovmand, R. (1983) Samspillet mellem Nordens folkehøjskoler indtil anden verdenskrig. Skrifter udgivet af Jysk Selskab for Historie, vol. 41. Aarhus: Universitetsforlaget.

Trägårdh, L. (1990) 'Varieties of völkish ideologies. Sweden and Germany 1848-1933', in Stråht, B. (ed.) Language and the construction of class identities. The struggle for discursive power in social organisation: Scandinavia and Germany after 1800, Report from the DISCO II Conference, Gothenberg: Göteborg University.

Tveit, S. (2014) 'Educational assessment in Norway', Assessment in Education: Principles, Policy E Practice 21(2), pp. 221-237. doi: 10.1080/0969594X.2013.830079.

Wermke, W. and Prøitz, T.S. (2019) 'Discussing the curriculum-Didaktik dichotomy and comparative conceptualisations of the teaching profession', Education Inquiry 10(4), pp. 300-327. doi: 10.1080/20004508.2019.1618677.

Wiborg, S. (2009) Education and social integration: comprehensive schooling in Europe. New York: Palgrave Macmillan.

Wiborg, S. (2017) 'Teacher unions in the Nordic Countries: solidarity and the politics of self-interest', in Moe, T.M. and Wiborg, S. (ed.) The comparative politics of education. Cambridge studies in the comparative politics of education. Cambridge: Cambridge University Press. 